\title{
Kombinasi Metode Correlated Naive Bayes dan Metode Seleksi Fitur Wrapper untuk Klasifikasi Data Kesehatan
}

\author{
Hairani $^{1}$ dan Muhammad Innuddin ${ }^{2}$ \\ ${ }^{1}$ Program Studi Ilmu Komputer, Fakultas Teknik dan Desain, Universitas Bumigora \\ ${ }^{2}$ Program Studi Sistem Informasi, Fakultas Teknik dan Desain, Universitas Bumigora \\ Jl. Ismail Marzuki No.22, Mataram, 83127, Indonesia \\ Hairani@universitasbumigora.ac.id ${ }^{1}$,Inn@universitasbumigora.ac.id ${ }^{2}$
}

\begin{abstract}
Most features of heal th data that have many irrelevant features can reduce the performance of classification method. One heal th data that has many attributes is the Pima Indian Diabetes dataset and Thyroid. Diabetes is a deadly disease caused by the increasing of blood sugar because of the body's inability to produce enough insulin and its complications can lead to heart attacks and strokes. The purpose of this research is to do a combination of Correlated Naïve Bayes method and Wrapper-based feature selection to classification of health data. The stages of this research consist of several stages, namely; (1) the collection of Pima Indian Diabetes and Thyroid dataset from UCI Machine Learning Repository, (2) pre-processing data such as transformation, Scaling, and Wrapper-based feature selection, (3) classification using the Correlated Naive Bayes and Naive Bayes methods, and (4) performance test based on its accuracy using the 10-fold cross validation method. Based on the results, the combination of Correlated Naive Bayes method and Wrapper-based feature selection get the best accuracy for both datasets used. For Pima Indian Diabetes dataset, the accuracy is 71,4\% and the Thyroid dataset accuracy is $79,38 \%$. Thus, the combination of Correlated Naïve Bayes method and Wrapper-based feature selection result in better accuracy without feature selection with an increase of 4,1\% for Pima Indian Diabetes dataset and $0,48 \%$ for the Thyroid dataset.
\end{abstract}

Keywords-Correlated Naive Bayes, Wrapper feature selection, Pima Indian Diabetes dataset, Thyroid dataset, health data

Abstrak-Kebanyakan fitur pada data kesehatan terdapat fitur tidak relevan sehingga dapat menu runkan kinerja metode klasifikasi. Salah satu data kesehatan yang memiliki atribut banyak adalah Pima Indian Diabetes dan Thyroid. Penyakit diabetes merupakan salah satu penyakit mematikan yang disebabkan meningkatn ya gula darah yang diakibatkan oleh ketidakmampuan tubuh menghasilkan insulin yang cukup dan komplikasinya dapat mengakibatkan serangan jantung dan stroke. Tujuan dari penelitian ini adalah melakukan kombinasi metode Correlated Naive Bayes dan seleksi fitur berbasis Wrapper untuk klasifikasi data kesehatan. Tahapan penelitian ini terdiri dari beberapa tahapan yaitu (1) pengumpulan dataset Pima Indian Diabetes dan Thyroid dari UCI Machine Learning Repository, (2) data pre-processing seperti transformasi, scaling, dan seleksi fitur berbasis Wrapper, (3) klasifikasi menggunakan metode Correlated Naive Bayes dan Naive Bayes, dan (4) pengujian kinerja berdasarkan akurasinya menggunakan metode validasi 10-fold cross validation. Berdasarkan hasil pengujian yang telah dilakukan, kombinasi metode Correlated Naive Bayes dengan seleksi fitur berbasis Wrapper mendapatkan akurasi terbaik kedua dataset yang digunakan. Untuk dataset Pima Indan Diabetes aku rasinya sebesar $71,4 \%$ dan aku rasi dataset Thyroid sebesar 79,38\%. Dengan demikian, kombinasi metode Correlated Naive Bayes dan seleksi fitur berbasis Wrapper menghasilkan akurasi lebih baik tanpa seleksi fitur dengan kenaikan sebesar 4,1\% untuk dataset Pima Indian Diabetes dan $0,48 \%$ dataset Thyroid.

Kata kunci-Correlated Naive Bayes, seleksi fitur Wrapper, dataset Pima Indian Diabetes, dataset Thyroid, data kesehatan

\section{PENDAhUluan}

Untuk meningkatkan ketepatan klasifikasi pada data kesehatan membutuhkan metode klasifikasi dengan kinerja yang baik. Bagaimanapun, jumlah data kesehatan yang diperoleh dari mesin digital memiliki fitur yang banyak dan tidak semua atributnya relevan digunakan untuk klasifikasi penyakit [1]. Kebanyakan fitur pada data kesehatan terdapat fitur tidak relevan sehingga dapat menurunkan kinerja metode klasifikasi. Salah satu data kesehatan yang memiliki banyak atribut adalah Pima Indian Diabetes dan Thyroid. Penyakit diabetes merupakan salah satu penyakit mematikan yang disebabkan meningkatnya gula darah dalam tubuh [2]. Penyakit diabetes disebabkan ketidakmampuan tubuh memproduksi insulin yang cukup. Komplikasi penyakit diabetes dapat menyebabkan serangan jantung dan stroke. Salah satu cara untuk meningkatkan akurasi metode klasifikasi adalah penggunaan pemilihan fitur. Pemilihan fitur 
merupakan teknik pra-pengolahan sangat penting untuk me milih fitur-fitur yang berpengaruh pada sebuah dataset [3]. Pemilihan fitur digunakan untuk memilih fitur-fitur yang berpengaruh, menghapus fitur tidak relevan pada atribut dataset, waktu komputasi menjadi cepat, dan dapat men ingkatkan kinerja dari metode klasifikasi [4], [5]. Teknik pemilihan fitur dibagi menjadi 3 kelompok yaitu Filter, Wrapper, dan Embedded [4]. Penelitian pemilihan fitur berbasis Filter dilakukan oleh [6]-[8], berbas is Wrapper oleh [3], [5], dan embedded [9]. Penelitian ini menggunakan teknik pemilihan fitur berbasis Wrapper dikarenakan memiliki kinerja lebih baik dari pemilihan fitur berbasis Filter [10] dan Embedded [11].

Metode klasifikasi yang digunakan penelitian ini adalah algoritma Correlated Naive Bayes. Algoritma Correlated Naive Bayes adalah sebuah algoritma hasil pengembangan Naive Bayes. Parameter-parameter yang ditambahkan pada algoritma Correlated Naive Bayes adalah nilai korelasi antar fitur X dengan kelasnya dan bilangan laplacian. Perhitungan korelasi ( $R$-Square) dilakukan untuk menunjukkan hubungan antar fitur dengan kelasnya pada algoritma Correlated Naive Bayes [12]. Bilangan laplacian digunakan untuk menghindari terjadinya zero probability. Untuk meningkatkan akurasi algorit ma Correlated Naive Bayes dapat menggunakan teknik pemilihan fitur.

Penelitian dibidang data mining untuk klasifikasi penyakit sudah banyak dilakukan diantaranya adalah penelitian [13] melakukan klasifikasi penyakit diabetes menggunakan metode Correlated Naive Bayes dan Naive Bayes. Kelemahan penelitian ini tidak menggunakan seleksi fitur untuk memilih atribut yang relevan. Penelitian [14] mengatasi permasalahan ketidakseimbangan kelas pada dataset Pima Indian Diabetes menggunakan metode K-Means-Smote. Kelemahan penelitian tersebut tidak menggunakan proses seleksi fitur sebelum melakukan klasifikasi menggunakan metode C4.5, Support Vektor Machine (SVM), dan Naive Bayes. Penelitian [15] melakukan diagnosis penyakit rematik menggunakan penalaran maju dan metode faktor kepastian.

Penelitian [16] menggunakan teknik pemilihan fitur Information Gain untuk me milih fitur yang berpengaruh untuk deteksi penyakit jantung. Penelitian [17] mengimplementasikan teknik pemilihan fitur Hybrid untuk prediksi diabetes melitus. Teknik pemilihan fitur berbasis Filter menggunakan Information Gain, sedangkan berbasis Wrapper menggunakan SVM sebagai algoritma pembelajarannya dan Sequential Backward Search (SBS). Penelitian [18] melakukan perbandingan teknik pemilihan fitur Information Gain dan Relief untuk deteksi penyakit gagal ginjal kronis. Berdasarkan hasil penelitiannya, metode seleksi fitur Relief memiliki kinerja lebih baik dari Information Gain.

Berdasarkan uraian di atas, terdapat gap penelitian ini dengan penelitian sebelumnya yaitu belum ada penelitian yang mengkombinasikan metode Correlated Naive Bayes dan seleksi fitur berbasis Wrapper untuk klasifikasi data kesehatan yang memiliki banyak fitur. Sebagai perbandingan penelitian
[13] menggunakan algoritma Correlated Naive Bayes untuk klasifikasi penyakit diabetes tanpa menggunakan seleksi fitur.

Oleh karena itu, penelitian ini mengkombinasikan algoritma Correlated Naive Bayes dan seleksi fitur berbasis Wrapper untuk klasifikasi data kesehatan untuk mendapatkan akurasi optimal.

\section{METODE}

Untuk menyelesaikan penelitian ini, aliran penelitian yang digunakan ditunjukkan pada Gambar 1. Tahapan pertama melakukan pengumpulan dataset kesehatan. Dataset dibidang kesehatan yang digunakan adalah dataset pima indians diabetes dan dataset Thyroid diperoleh dari UCI Machine Learning Repository. Detail dataset penelitian ini ditunjukkan pada Tabel I. Adapun detail atribut pada dataset yang digunakan ditunjukkan pada Tabel II dan Tabel III.

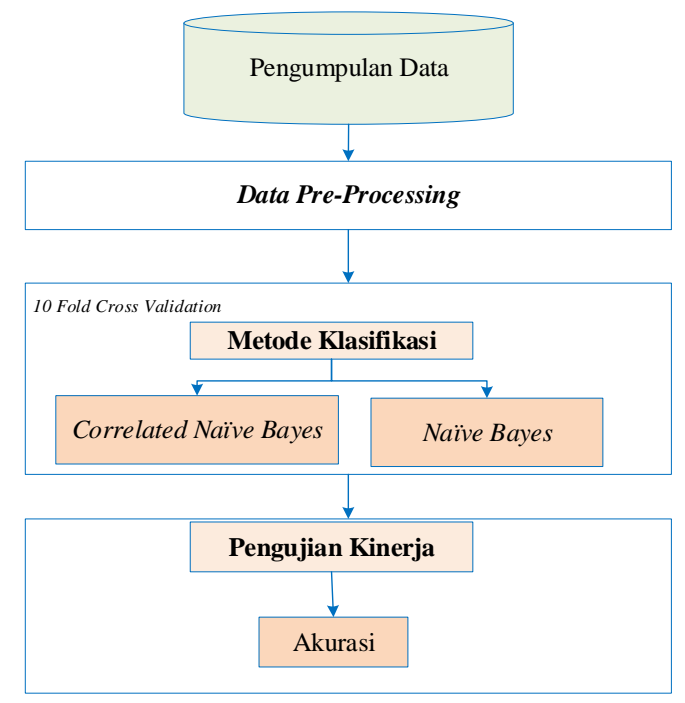

Gambar 1. Tahapan penelitian

TABEL I. DETAIL DATASET

\begin{tabular}{|c|l|c|c|c|}
\hline No & \multicolumn{1}{|c|}{ Dataset } & Data & Atribut & Kelas \\
\hline 1. & $\begin{array}{l}\text { Pima Indian } \\
\text { Diabetes }\end{array}$ & 768 & 9 & 2 \\
\hline 2. & Thyroid & 215 & 6 & 3 \\
\hline
\end{tabular}

TABEL II. ATRIBUt DATASET PIMA INDIAN DiABETES

\begin{tabular}{|c|l|l|l|}
\hline No & \multicolumn{1}{|c|}{ Atribut } & Label & \multicolumn{1}{|c|}{ Deskripsi } \\
\hline 1. & $\begin{array}{l}\text { Number of times } \\
\text { pregnant }\end{array}$ & NP & Jumlah kehamilan \\
\hline 2. & Plasma glucose & GTT & Kadar glukosa \\
\hline 3. & Blood pressure & DBP & Tekanan darah \\
\hline 4. & Skin thickness & TSF & Ketebalan kulit \\
\hline 5. & Insulin & HSI & Insulin \\
\hline 6. & BMI & BMI & Berat masa tubuh \\
\hline 7. & $\begin{array}{l}\text { Diabetes pedigree } \\
\text { function }\end{array}$ & DPF & $\begin{array}{l}\text { Riway at peny akit } \\
\text { keluarga }\end{array}$ \\
\hline 8. & Age & Age & Umur \\
\hline 9. & $\begin{array}{l}\text { Tested Negative and } \\
\text { Tested Positive }\end{array}$ & Kelas & \\
\hline
\end{tabular}


TABEL III. ATRIBUT DATASET THYROID

\begin{tabular}{|c|l|l|}
\hline No. & \multicolumn{1}{|c|}{ Atribut } & Label \\
\hline 1. & T3-resin uptake test & RUT \\
\hline 2. & Total serum thyroxin & TST \\
\hline 3. & Total serum triiodothyronine & TSTD \\
\hline 4. & Basal thyroid-stimulating hormone (TSH & TSH \\
\hline 5. & $\begin{array}{l}\text { Maximal absolute difference of TSH } \\
\text { value }\end{array}$ & MAD \\
\hline 6. & $\begin{array}{l}\text { Normal } \\
\text { Hyper } \\
\text { Hypo }\end{array}$ & Kelas \\
\hline
\end{tabular}

Tahapan pra-pengolahan digunakan penelitian ini adalah transformasi, scaling, dan pemilihan fitur. Transformasi digunakan untuk merubah tipe atribut nominal menjadi angka. Perhitungan korelasi (R-Square) dilakukan untuk menunjukkan hubungan antar fitur dengan kelasnya pada algoritma Correlated Naive Bayes.

Scaling digunakan untuk mimalisir terjadinya dominasi fitur dengan jangkauan nilai terbesar $\left(\max _{\mathrm{x}}\right)$ terhadap fitur dengan jangkauan nilai terkecil $\left(\min _{x}\right)$. Formulasi yang digunakan untuk melakukan scaling ditunjukkan pada (1).

Sedangkan pemilihan fitur digunakan untuk menghapus fitur tidak relevan dan memilih fitur yang berpengaruh pada dataset Pima Indian Diabetes dan Thyroid. Teknik pemilihan fitur Wrapper digunakan pada penelitian ini adalah SVM sebagai algorit ma pembelajarannya dan Sequential Backward Search (SBS). Teknik pemilihan fitur Wrapper dalam pemilihan atributnya melibatkan algoritma pembelajaran. Adapun proses kerja dari metode pemilihan fitur Wrapper ditunjukkan pada Gambar 2.

$$
X^{\prime}=\frac{x-\min _{x}}{\max _{x}-\min _{x}}
$$

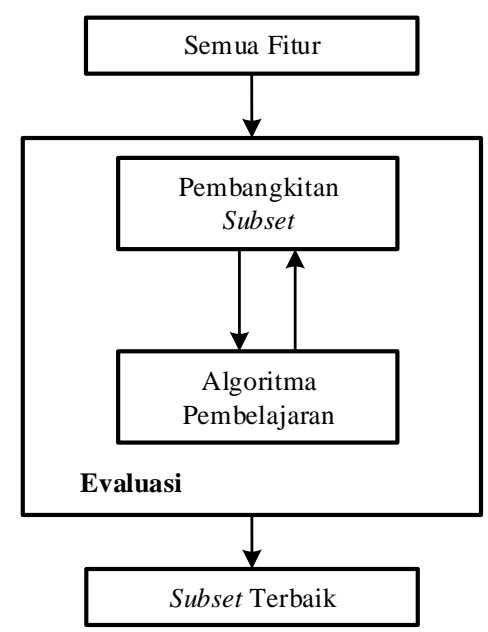

Gambar 2. Proses pemilihan fitur berbasis Wrapper [19]

Algoritma Correlated Naive Bayes adalah sebuah algoritma hasil pengembangan Naive Bayes. Parameterparameter yang ditambahkan pada algorit ma Correlated Naive Bayes adalah nilai kore lasi antar fitur X dengan kelasnya dan bilangan laplacian. Perhitungan korelasi ( $R$-Square) dilakukan untuk menunjukkan hubungan antar fitur dengan kelasnya pada algoritma Correlated Naive Bayes [12]. Bilangan laplacian digunakan untuk menghindari terjadi zero probability. Rumus algoritma Correlated Naive Bayes untuk klasifikasi ditunjukkan pada (2) [12], serta rumus perhitungan korelasinya ditunjukkan pada (3) dan (4).

$$
P(Y \mid X)=\frac{P(Y) \prod_{i=1}^{q} P\left(X_{i} \mid Y\right)^{\ell} \cdot R\left(X_{i} \mid Y\right)}{P(X)}
$$

$P(X \mid Y)$ merupakan probabilitas hipotesis $\mathrm{Y}$ berdasarkan kejadian $\mathrm{X} . \mathrm{P}(\mathrm{Y})$ merupakan prior probability pada hipotes is Y. $\Pi_{i=1}^{q}\left(X_{i} \mid Y\right)$ merupakan probabilitas fitur $\mathrm{X}$ berdasarkan hipotesis Y. $R\left(X_{i} \mid Y\right)$ merupakan korelasi ( $R$-Square) fitur $\mathrm{X}$ berdasarkan hipotesis Y. $\ell$ merupakan bilangan laplacian, sedangkan $P(X)$ merupakan probabilitas $\mathrm{X}$.

$$
\begin{gathered}
r=\frac{n \cdot\left(\sum X Y\right)-\left(\sum X\right) \cdot\left(\sum Y\right)}{\sqrt{\left(n \cdot \sum X^{2}-\left(\sum X\right)^{2}\right) \sqrt{n \cdot \sum Y^{2}-(Y)^{2}}}} \\
\mathrm{R}=\mathrm{r}^{2}
\end{gathered}
$$

$R$ merupakan $R$-Square fitur antar kelasnya, sedangkan $r$ merupakan nilai korelasi fitur antar kelasnya. n merupakan total data pada dataset. $\sum X Y$ merupakan total perkalian fitur (X) dengan kelasnya (Y). $\sum X$ merupakan total dari fitur $\mathrm{X}$, sedangkan $\sum Y$ merupakan total dari fitur Y. $\sum X^{2}$ merupakan total dari fitur $\mathrm{X}$ yang dikuadratkan, sedangkan $\left(\sum X\right)^{2}$ merupakan kuadrat total fitur X. $\sum Y^{2}$ merupakan total fitur $\mathrm{Y}$ yang dikuadratkan, sedangkan $\left(\sum Y\right)^{2}$ merupakan kuadrat total fitur Y.

\section{HASIL DAN PEMBAHASAN}

\section{A. Pengumpulan Data}

Pengumpulan dataset diperoleh dari UCI Machine Learning Repository. Dataset yang digunakan penelitian ini adalah dataset Thyroid dan Pima Indian Diabetes yang ditunjukkan pada Tabel IV dan Tabel V.

TABEL IV. CONTOH DATASET THYROID

\begin{tabular}{|c|r|r|c|r|r|l|}
\hline No. & RUT & TS T & TS TD & TSH & MAD & Kelas \\
\hline 1. & 107 & 10,1 & 2,2 & 0,9 & 2,7 & Normal \\
\hline 2. & 113 & 9,9 & 3,1 & 2,0 & 5,9 & Normal \\
\hline 3. & 139 & 16,4 & 3,8 & 1,1 & $-0,2$ & Hyper \\
\hline 4. & 125 & 2,3 & 0,9 & 16,5 & 9,5 & Hypo \\
\hline$\cdots$ & $\cdots$ & $\cdots$ & $\cdots$ & $\cdots$ & $\cdots$ & $\cdots$ \\
\hline 211. & 104 & 6,1 & 1,8 & 0,5 & 0,8 & Normal \\
\hline 212. & 102 & 6,2 & 1,2 & 1,4 & 1,3 & Normal \\
\hline 213. & 102 & 5,3 & 1,4 & 1,3 & 6,7 & Hypo \\
\hline 214. & 79 & 19,0 & 5,5 & 0,9 & 0,3 & Hyper \\
\hline 215. & 92 & 11,1 & 1,2 & 0,7 & $-0,2$ & Hyper \\
\hline
\end{tabular}


TABEL V. CONTOH DATASET PIMA INDIAN DiABETES

\begin{tabular}{|c|c|c|c|c|c|c|c|c|c|}
\hline No. & $\mathbf{N P}$ & GTT & $\overline{\text { DBP }}$ & TSF & $\overline{\text { HS1 }}$ & $\overline{\text { BMI }}$ & $\overline{\text { DPF }}$ & Age & Kelas \\
\hline 1. & 1 & 85 & 66 & 29 & 0 & 26,6 & 0,351 & 31 & Negative \\
\hline 2. & 1 & 89 & 66 & 23 & 94 & 28,1 & 0,167 & 21 & Negative \\
\hline 3. & 5 & 116 & 74 & 0 & 0 & 25,6 & 0,201 & 30 & Negative \\
\hline 4. & 10 & 115 & 0 & 0 & 0 & 25,2 & 0,134 & 29 & Negative \\
\hline ; & $\ldots$ & $\ldots$ & $\ldots$ & $\ldots$ & & & $\ldots$ & $\ldots$ & $\ldots$ \\
\hline 764. & 1 & 128 & 88 & 39 & 110 & 36,5 & 1,057 & 37 & Positive \\
\hline 765 . & 0 & 123 & 72 & $\overline{0}$ & 0 & 36,3 & 0,258 & 52 & Positive \\
\hline 766. & 6 & 190 & 92 & 0 & 0 & 35,5 & 0,278 & 66 & Positive \\
\hline 767. & 9 & 170 & $\overline{74}$ & 31 & 0 & 44,0 & 0,403 & 43 & Positive \\
\hline 768. & 1 & 126 & 60 & 0 & 0 & 30,1 & 0,349 & 47 & Positive \\
\hline
\end{tabular}

\section{B. Pra-pengolahan Data}

Tahapan pra-pengolahan digunakan penelitian ini adalah transformasi, scaling, seleksi fitur. Transformasi digunakan untuk merubah tipe atribut nominal menjadi angka. Perhitungan korelasi ( $R$-Square) dilakukan untuk menunjukkan hubungan antar fitur dengan kelasnya pada algorit ma Correlated Naive Bayes. Hasil transformasi atribut ditunjukkan pada Tabel VI dan Tabel VII.

Scaling digunakan untuk mimalisir terjadinya dominasi fitur dengan jangkauan nilai terbesar terhadap fitur dengan jangkauan nilai terkecil. Formulasi yang digunakan untuk melakukan scaling ditunjukkan pada (1). Contoh hasil scaling pada dataset Pima Indian Diabetes ditunjukkan pada Tabel VIII.

TABEL VI. TRANSFormasi DATASET Pima INDIAN DiabeteS

\begin{tabular}{|c|l|c|}
\hline No. & \multicolumn{1}{|c|}{ Data Nominal } & Data Angka \\
\hline 1. & Negative & 1 \\
\hline 2. & Positive & 2 \\
\hline
\end{tabular}

TABEL VII. TRANSFORMASI DATASET T HYROID

\begin{tabular}{|c|l|c|}
\hline No. & \multicolumn{1}{|c|}{ Data Nominal } & Data Angka \\
\hline 1. & Normal & 1 \\
\hline 2. & Hyper & 2 \\
\hline 3. & Hypo & 3 \\
\hline
\end{tabular}

Sebagai contoh hasil scaling atribut GTT pada dataset Pima Indian Diabetes untuk nilai 89 dimana nilai maksimum dan minimumnya adalah 139 dan 85 adalah sebagaiberikut:

$$
X^{\prime}=\frac{x-\min _{x}}{\max _{x}-\min _{x}}=\frac{89-85}{139-85}=0,074
$$

Sedangkan pemilihan fitur digunakan untuk menghapus fitur tidak relevan dan memilih fitur yang berpengaruh pada dataset Pima Indian Diabetes dan Thyroid. Teknik pemilihan fitur Wrapper digunakan pada penelitian ini adalah SVM sebagai algoritma pembelajarannya berdasarkan (4) mengacu penelitian [20] dan Sequential Backward Search (SBS). Adapun hasil fitur yang terpilih menggunakan teknik pemilihan fitur Wrapper ditunjukkan pada Tabel IX.

\section{Klasifikasi}

Metode klasifikasi penelitian ini menggunakan metode Correlated Naive Bayes berdasarkan (2).
TABEL VIII. HASIL SCAUNG ATRIBUT GTT PADA DATASET PIMA INDIAN DIABETES

\begin{tabular}{|c|c|c|}
\hline No. & Tanpa Scaling & Hasil Scaling \\
\hline 1. & $89(\mathrm{Mg} / \mathrm{dL})$ & 0,074 \\
\hline 2. & $85(\mathrm{Mg} / \mathrm{dL})$ & 0 \\
\hline 3. & $116(\mathrm{Mg} / \mathrm{dL})$ & 0,574 \\
\hline 4. & $115(\mathrm{Mg} / \mathrm{dL})$ & 0,556 \\
\hline 5. & $110(\mathrm{Mg} / \mathrm{dL})$ & 0,463 \\
\hline 6. & $139(\mathrm{Mg} / \mathrm{dL})$ & 1 \\
\hline 7. & $103(\mathrm{Mg} / \mathrm{dL})$ & 0,333 \\
\hline 8. & $126(\mathrm{Mg} / \mathrm{dL})$ & 0,759 \\
\hline 9. & $99(\mathrm{Mg} / \mathrm{dL})$ & 0,259 \\
\hline 10. & $97(\mathrm{Mg} / \mathrm{dL})$ & 0,222 \\
\hline
\end{tabular}

TABEL IX. ATRIBUt TERPILIH HASIL SELEKSI FITUR

\begin{tabular}{|l|l|l|}
\hline \multicolumn{1}{|c|}{ Dataset } & \multicolumn{1}{|c|}{ Atribut Original } & Atribut Terpilih \\
\hline $\begin{array}{l}\text { Pima Indian } \\
\text { Diabetes }\end{array}$ & $\begin{array}{l}\text { NP, GTT, DBP, TSF, HSI, } \\
\text { BMI, DBF, Age }\end{array}$ & GTT, DBF \\
\hline Thyroid & RUT, TST, TSTD, TSH, & $\begin{array}{l}\text { TST, TSTD, } \\
\text { TSH, M AD }\end{array}$ \\
\hline
\end{tabular}

\section{Pengujian Kinerja}

Metode 10-fold cross validation digunakan untuk memvalidasi hasil akurasi metode Correlated Naive Bayes tiap-tiap fold. Metode 10-fold cross validation membagi data sebanyak 10 data tiap-tiap fold. Hasil akurasi tiap-tiap fold ditunjukkan pada Tabel $\mathrm{X}$ dan Tabel XI. Untuk mempermudah melihat nilai akurasi metode Correlated Naive Bayes ditunjukkan pada Tabel XII.

Berdasarkan pada Tabel XII, ditunjukkan akurasi terbaik diperoleh metode Correlated Naive Bayes dengan seleksi fitur pada dataset Pima Indian Diabetes sebesar 71,4\%, sedangkan pada dataset Thyroid akurasinya sebesar 79,38\%. Dengan demikian, penggunaan seleksi fitur Wrapper dapat men ingkatkan akurasi metode Correlated Naive Bayes sebesar 4,1\% untuk dataset Pima Indian Diabetes dan sebesar 0,48\% untuk dataset Thyroid, dikarenakan hanya mengklasifikasikan fitur-fitur yang relevan [21]. Hal ini selaras dengan dengan penelitian [22]-[24] menggunakan teknik seleksi fitur untuk meningkatkan akurasi metode klasifikasi yang digunakan. Kebanyakan referensi seperti [13], [25], dan [26] hanya implementasi metode Correlated Naive Bayes, sehingga 
penelitian ini menggunakan metode seleksi fitur untuk meningkatkan akurasi algoritma Correlated Naive Bayes.

TABEL $\mathrm{X}$. AKURASI DATASET PIMA INDIAN DIABETES

\begin{tabular}{|c|c|c|c|c|}
\hline \multirow[b]{2}{*}{ Fold } & \multicolumn{2}{|c|}{ Correlated Naive Bayes } & \multicolumn{2}{|c|}{ Naive Bayes } \\
\hline & $\begin{array}{c}\text { Tanpa } \\
\text { Pemilihan } \\
\text { Fitur }\end{array}$ & $\begin{array}{c}\text { Pemilihan } \\
\text { Fitur }\end{array}$ & $\begin{array}{c}\text { Tanpa } \\
\text { Pemilihan } \\
\text { Fitur }\end{array}$ & $\begin{array}{c}\text { Pemilihan } \\
\text { Fitur }\end{array}$ \\
\hline 1. & $67,89 \%$ & $73,29 \%$ & $63,95 \%$ & $70,39 \%$ \\
\hline 2. & $67,50 \%$ & $63,16 \%$ & $63,95 \%$ & $59,87 \%$ \\
\hline 3. & $67,37 \%$ & $72,11 \%$ & $64,34 \%$ & $71,40 \%$ \\
\hline 4. & $66,71 \%$ & $73,03 \%$ & $63,82 \%$ & $72,24 \%$ \\
\hline 5. & $67,37 \%$ & $\mathbf{7 2 , 8 9 \%}$ & $65,53 \%$ & $70,13 \%$ \\
\hline 6. & $66,97 \%$ & $\overline{72,63 \%}$ & $64,47 \%$ & $69,61 \%$ \\
\hline 7. & $67,37 \%$ & 71,97\% & $64,87 \%$ & $71,84 \%$ \\
\hline 8. & $67,24 \%$ & $\overline{72,24 \%}$ & $63,29 \%$ & $70,92 \%$ \\
\hline 9. & $67,37 \%$ & $72,24 \%$ & $63,68 \%$ & $70,39 \%$ \\
\hline 10. & $67,24 \%$ & $72,37 \%$ & $64,74 \%$ & $71,71 \%$ \\
\hline
\end{tabular}

TABEL XI. AKURASI DATASET THYROID

\begin{tabular}{|c|c|c|c|c|}
\hline \multirow{2}{*}{ Fold } & \multicolumn{2}{|c|}{ Correlated Naive Bayes } & \multicolumn{2}{|c|}{ Naive Bayes } \\
\cline { 2 - 5 } & $\begin{array}{c}\text { Tanpa } \\
\text { Pemilihan } \\
\text { Fitur }\end{array}$ & $\begin{array}{c}\text { Pemilihan } \\
\text { Fitur }\end{array}$ & $\begin{array}{c}\text { Tanpa } \\
\text { Pemilihan } \\
\text { Fitur }\end{array}$ & $\begin{array}{c}\text { Pemilihan } \\
\text { Fitur }\end{array}$ \\
\hline 1. & $80,00 \%$ & $\mathbf{8 0 , 4 8 \%}$ & $61,43 \%$ & $69,05 \%$ \\
\hline 2. & $77,62 \%$ & $\mathbf{7 8 , 5 7 \%}$ & $64,29 \%$ & $69,05 \%$ \\
\hline 3. & $80,95 \%$ & $\mathbf{8 1 , 4 3 \%}$ & $61,43 \%$ & $68,57 \%$ \\
\hline 4. & $78,57 \%$ & $\mathbf{7 9 , 5 2 \%}$ & $61,43 \%$ & $68,09 \%$ \\
\hline 5. & $79,05 \%$ & $\mathbf{7 9 , 0 5 \%}$ & $62,38 \%$ & $70,00 \%$ \\
\hline 6. & $78,57 \%$ & $\mathbf{7 8 , 5 7 \%}$ & $60,95 \%$ & $70,00 \%$ \\
\hline 7. & $77,62 \%$ & $\mathbf{7 8 , 0 9 \%}$ & $62,38 \%$ & $67,62 \%$ \\
\hline 8. & $78,57 \%$ & $\mathbf{7 9 , 0 5 \%}$ & $60,00 \%$ & $70,48 \%$ \\
\hline 9. & $77,14 \%$ & $\mathbf{7 8 , 5 7 \%}$ & $63,33 \%$ & $69,52 \%$ \\
\hline 10. & $\mathbf{8 0 , 9 5 \%}$ & $80,48 \%$ & $60,00 \%$ & $67,62 \%$ \\
\hline
\end{tabular}

TABEL XII. HASIL AKURASI METODE KLASIFIKASI

\begin{tabular}{|l|c|c|c|c|}
\hline \multirow{3}{*}{ Dataset } & \multicolumn{2}{|c|}{ Correlated Naive Bayes } & \multicolumn{2}{|c|}{ Naive Bayes } \\
\cline { 2 - 5 } & $\begin{array}{c}\text { Tanpa } \\
\text { Pemilihan } \\
\text { Fitur }\end{array}$ & $\begin{array}{c}\text { Pemilihan } \\
\text { Fitur }\end{array}$ & $\begin{array}{c}\text { Tanpa } \\
\text { Pemilihan } \\
\text { Fitur }\end{array}$ & $\begin{array}{c}\text { Pemilihan } \\
\text { Fitur }\end{array}$ \\
\hline $\begin{array}{l}\text { Pima } \\
\text { Indian } \\
\text { Diabetes }\end{array}$ & $67,30 \%$ & $\mathbf{7 1 , 4 0 \%}$ & $64,26 \%$ & $69,79 \%$ \\
\hline Thyroid & $78,90 \%$ & $\mathbf{7 9 , 3 8 \%}$ & $61,76 \%$ & $68,83 \%$ \\
\hline
\end{tabular}

\section{PENUTUP}

Metode Correlated Naive Bayes dan Wrapper menghasilkan akurasi lebih baik dibandingkan tanpa seleksi fitur pada dataset Pima Indian Diabetes dan Thyroid. Hal ini disebabkan metode Correlated Naive Bayes hanya mengklasifikasikan fitur-fitur yang relevan pada dataset yang digunakan sehingga terjadi kenaikan akurasi Pima Indian Diabetes sebesar $4,1 \%$ dan Thyroid sebesar $0,48 \%$. Penelitian selanjutnya dapat menggunakan kombinasi metode seleksi fitur berbasis Filter dan Wrapper untuk pemilihan atribut dataset kesehatan seperti Pima Indian Diabetes dan Thyroid.

\section{UCAPAN TERIMA KASIH}

Terima kasih kepada DRPM DIKTI untuk dana penelitian dalam skema Penelitian Dosen Pemula (PDP) tahun pelaksanaan 2020 yang sudah diberikan, sehingga penelitian ini dapat terlaksana.

\section{REFERENSI}

[1] J. D. Álvarez, J. A. Matias-Guiu, M. N. Cabrera-Martín, J. L. RiscoMartín, and J. L. Ayala, "An application of machine learning with feature selection to improve diagnosis and classification of neurodegenerative disorders," BMC Bioinformatics, vol. 20, no. 1, pp. 1-12, 2019, doi: 10.1186/s12859-019-3027-7.

[2] D. Sisodia and D. S. Sisodia, "Prediction of Diabetes using Classification Algorithms," Procedia Comput. Sci., vol. 132, no. Iccids, pp. 1578-1585, 2018, doi: 10.1016/j.procs.2018.05.122.

[3] M. A. Fahmiin and T. H. Lim, "Evaluating the Effectiveness of Wrapper Feature Selection Methods with Artificial Neural Net work Classifier for Diabetes Prediction," in Testbeds and Research Infrastructures for the Development of Networks and Communications, 2020, pp. 3-17.

[4] J. C. Ang, A. Mirzal, H. Haron, and H. N. A. Hamed, "Supervised, unsupervised, and semi-supervised feat ure selection: A review on gene selection," IEEE/ACM Trans. Comput. Biol. Bioinforma., vol. 13, no. 5, pp. 971-989, 2016, doi: 10.1109/TCBB.2015.2478454.

[5] N. K. Suchetha, A. Nikhil, and P. Hrudya, "Comparing the Wrapper Feat ure Selection Evaluators on Twitter Sentiment Classification," in 2019 Intemational Conference on Computational Intelligence in Data Science (ICCIDS), 2019, pp. 1-6, doi: 10.1109/ICCIDS.2019.8862033.

[6] E. Hancer, B. Xue, and M. Zhang, "Differential evolution for filter feature selection based on information theory and feature ranking," Knowledge-Based Syst., vol. 140, pp. 103-119, 2018, doi: 10.1016/j.knosys.2017.10.028.

[7] S. L. Shiva Darshan and C. D. Jaidhar, "Performance Evaluation of Filter-based Feature Selection Techniques in Classifying Portable Executable Files," Procedia Comput. Sci., vol. 125, pp. 346-356, 2018, doi: 10.1016/j.procs.2017.12.046.

[8] M. Alirezanejad, R. Enayatifar, H. Motameni, and H. Nematzadeh, "Heuristic filter feature selection methods for medical datasets," Genomics, vol. 112, no. 2, pp. 1173-1181, 2020, doi: 10.1016/j.y geno.2019.07.002.

[9] H. Zhou, X. Wang, and Y. Zhang, "Feature selection based on weighted conditional mutual information," Appl. Comput. Informatics, no. xxxx, 2020, doi: 10.1016/j.aci.2019.12.003.

[10] C. Liu, W. Wang, Q. Zhao, X. Shen, and M. Konan, "A new feat ure selection method based on a validity index of feat ure subset," Pattern Recognit. Lett., vol. 92, pp. 1-8, 2017, doi: 10.1016/j.patrec.2017.03.018.

[11] S. S. Hameed, O. O. Petinrin, A. O. Hashi, and F. Saeed, "Filterwrapper combination and embedded feature selection for gene expression data," Int. J. Adv. Soft Comput. its Appl., vol. 10, no. 1, pp. $90-105,2018$.

[12] B. A. Muktamar, N. A. Setiawan, and T. B. Adji, "Pembobotan Korelasi pada Naive Bayes Classifier," Semin. Nas. Teknol. Inf. dan Multimed. 2015 STMIK AMIKOM Yogyakarta, 6-8 Februari 2015, no. 1, pp. 43-47, 2015.

[13] H. Hairani, G. Nugraha, M. Nurkholis Abdillah, and M. Innuddin, "Komparasi Akurasi Metode Correlated Naive Bayes Classifier dan Naive Bayes Classifier untuk Diagnosis Penyakit Diabetes," InfoTekJar(Jurnal Nasional Informatika dan Teknologi Jaringan), vol. 3, no. 1, pp. 6-11,2018, doi: 10.30743/infotekjar.v3i1.558

[14] H. Hairani, K. E. Saputro, and S. Fadli, "K-means-SMOTE untuk menangani ketidakseimbangan kelas dalam klasifikasi penyakit diabetes dengan C4.5, SVM, dan naive Bayes," Jumal Teknologi. dan Sistem Komputer, vol. 8, no. 2, pp. 89-93, Apr. 2020, doi: https://doi.org/10.14710/jtsiskom.8.2.2020.89-93.

[15] Hairani, M. N. Abdillah, and M. Innuddin, "An Expert System for Diagnosis of Rheumatic Disease Types Using Forward Chaining Inference and Certainty Factor Method," in 2019 Intemational Conference on Sustainable Information Engineering and Technology (SIET), 2019, pp. 104-109, doi: 10.1109/SIET48054.2019.8986035. 
[16] S. H. A. Aini, Y. A. Sari, and A. Arwan, "Seleksi Fitur Information Gain untuk Klasifikasi Penyakit Jantung Menggunakan Kombinasi Metode K-Nearest Neighbor dan Naïve Bayes," J. Pengemb. Teknol. Inf. dan Ilmu Komputer; Vol 2 No 9, vol. 2, no. 9, pp. 2546-2554, Feb. 2018.

[17] H. Zheng, H. W. Park, D. Li, K. H. Park, and K. H. Ryu, “A Hybrid Feature Selection Approach for Applying to Patients with Diabetes Mellitus: KNHANES," in 2018 5th NAFOSTED Conference on Information and Computer Science (NICS), 2018, pp. 110-113.

[18] F. Kayaalp, M. S. Basarslan, and K. Polat, "A hybrid classification example in describing chronic kidney disease," in 2018 Electric Electronics, Computer Science, Biomedical Engineerings' Meeting (EBBT), 2018, pp. 1-4, doi: 10.1109/EBBT.2018.8391444.

[19] N. El Aboudi and L. Benhlima, "Review on wrapper feature selection approaches," in 2016 Intemational Conference on Engineering \& MIS (ICEMIS), 2016,pp. 1-5, doi: 10.1109/ICEMIS.2016.7745366.

[20] S. Manikandan, E. Susi, and S. Abirami, "Feature Selection on High Dimensional Data using Wrapper Based Subset Selection,” in 2017 Second Intemational Conference on Recent Trend and Challenges in Computational Models, 2017, pp. 320-325, doi: 10.1109/ICRTCCM.2017.58.
[21] O. Somantri and M. Khambali, "Feature Selection Klasifikasi Kategori Cerita Pendek Menggunakan Naïve Bayes dan Algoritme Genetika," $J$. Nas. Tek. Elektro dan Teknol. Inf., vol. 6, no. 3, pp. 301-306, 2017, doi: 10.22146/jnteti.v6i3.332.

[22] I. Santoso, W. Gata, and A. B. Paryanti, "Penggunaan Feature Selection di Algoritma Support Vector Machine untuk Sentimen Analisis Komisi Pemilihan Umum," Rekayasa Sist. dan Teknol. Inf., vol. 3, no. 3, pp. 364-370, 2019.

[23] R. Nair and A. Bhagat, "Feature selection method to improve the accuracy of classification algorithm," Int. J. Innov. Technol. Explor. Eng., vol. 8, no. 6, pp. 124-127, 2019.

[24] H. Marcos and H. Utomo, "Perbandingan Kinerja Algoritme C.45 Dan Naive Bayes Mengklasifikasi Penyakit Diabetes," J. Inform., vol. 15, no. 2, pp. 141-148, 2015, doi: 10.30873/ji.v15i2.596.

[25] B. A. Muktamar, N. A. Setiawan, and T. B. Adji, "Analisis Perbandingan Tingkat AKurasi Algoritma Naive Bayes Classifier dengan Correlated-Naive Bayes Classifier," Semin. Nas. Teknol. Inf. dan Multimed. 2015 STMIK AMIKOM Yogyakarta, 6-8 Februari 2015, pp. 49-54, 2015.

[26] Z. Ulhaq and T. B. Adji, "Technique ( SMOTE) dengan Correlated Naïve Bayes pada Klasifikasi Siswa Berkesulitan Belajar," in CITEE, 2017, pp. 201-205. 